\title{
THE TRANSITION STUDY OF POSTSOCIALIST CHINA
}

\author{
An Ethnographic Study of \\ a Model Community
}


Series Editors: Joseph Fewsmith (Boston University)

Zheng Yongnian (East Asian Institute, National University of Singapore)

Published*

Vol. 13 China's Science and Technology Sector and the Forces of Globalisation edited by Elspeth Thomson \& Jon Sigurdson

Vol. 14 Migration and Social Protection in China edited by Ingrid Nielsen \& Russell Smyth

Vol. 15 China's Reforms at 30: Challenges and Prospects edited by Dali L Yang \& Litao Zhao

Vol. 16 Political Booms: Local Money and Power in Taiwan, East China, Thailand and the Philippines

by Lynn T White

Vol. 17 Politics of China's Environmental Protection: Problems and Progress by Chen Gang

Vol. 18 Oil in China: From Self-Reliance to Internationalization by Lim Tai Wei

Vol. 19 China's Elite Politics: Governance and Democratization by Bo Zhiyue

Vol. 20 China's New Social Policy: Initiatives for a Harmonious Society edited by Zhao Litao \& Lim Tin Seng

Vol. 21 Oil and Gas in China: The New Energy Superpower's Relations with Its Region by Lim Tai Wei

Vol. 22 China and The Global Economic Crisis edited by Zheng Yongnian \& Sarah Y. Tong

Vol. 23 Social Cohesion in Greater China: Challenges for Social Policy and Governance edited by Ka Ho Mok \& Yeun-Wen Ku

Vol. 24 China's Reform in Global Perspective edited by John Wong \& Zhiyue Bo

Vol. 25 The Transition Study of Postsocialist China: An Ethnographic Study of a Model Community by Wing-Chung Ho

*To view the complete list of the published volumes in the series, please visit: http://www.worldscibooks.com/series/scc_series.shtml 


\title{
Series on Contemporary China - Vol. 25 \\ THE TRANSITION STUDY OF POSTSOCIALIST CHINA
}

\author{
An Ethnographic Study of \\ a Model Community
}

\section{Wing-Chung Ho
(City University of Hong Kong, China) \\ Wing-Chung Ho
(City University of Hong Kong, China)}


Published by

World Scientific Publishing Co. Pte. Ltd.

5 Toh Tuck Link, Singapore 596224

USA office: 27 Warren Street, Suite 401-402, Hackensack, NJ 07601

UK office: 57 Shelton Street, Covent Garden, London WC2H 9HE

\section{British Library Cataloguing-in-Publication Data}

A catalogue record for this book is available from the British Library.

\section{Series on Contemporary China - Vol. 25 THE TRANSITION STUDY OF POSTSOCIALIST CHINA An Ethnographic Study of a Model Community}

Copyright (C) 2010 by World Scientific Publishing Co. Pte. Ltd.

All rights reserved. This book, or parts thereof, may not be reproduced in any form or by any means, electronic or mechanical, including photocopying, recording or any information storage and retrieval system now known or to be invented, without written permission from the Publisher.

For photocopying of material in this volume, please pay a copying fee through the Copyright Clearance Center, Inc., 222 Rosewood Drive, Danvers, MA 01923, USA. In this case permission to photocopy is not required from the publisher.

ISBN-13 978-981-4307-62-8

ISBN-10 981-4307-62-9

Printed in Singapore. 


\section{To my wife, Chuchu \\ and \\ son, Himhim}


This page intentionally left blank 


\section{PREFACE}

There is no denying that China has experienced, and is still experiencing, radical changes, generally initiated by the vibrant market-driven economy that began in the late 1970s. The question remains, however, of what has happened to those who, just a few decades earlier, experienced pride and a sense of power in being part of the proletariat. How do they make sense of the socialist past and face up to the uncertainties of the future? This book aims to explore their lives and memories in order to outline their experiences of a historically specific form of transition in urban China. I have chosen to study the residents of Cucumber Lane (Fangualong), a working-class neighborhood in Shanghai (Fig. 1). In the 1960 s, a socialist "model community" was formed from what had been an urban slum in the 1940s. It was further recast as a "civilized small community" in the 1990s.

This anthropological investigation, which was conducted in 2000-01, was based on oral histories as well as on ethnographic observations and pertinent historical materials. Data analysis is applied to portray the various ways the Chinese have been making sense of and coping with radical changes during a period punctuated by shifts in political priorities, vicissitudes in ideological orientation, and changes in the way people conceive of their relationship with the state and with enterprises, the (de-) politicization of social identities, the rise and fall of collectivism, and the explosive vitality of the new market economy.

In fact, living in Shanghai in the early 2000s, it would have been difficult to overlook the state propaganda aimed at touting economic and, ultimately, national progress. For instance, roadside billboards erected in 


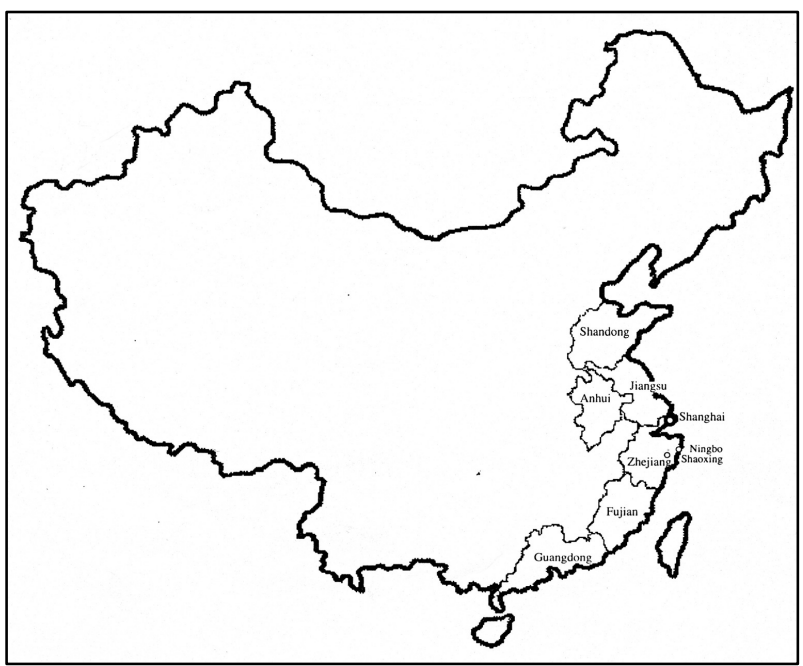

Figure 1. Outline Map of China. (showing Shanghai and eight provinces) (Source: Honig 1992, p.13)

busy streets read, "Development is an unshakable law" (fazhan shi ying daoli) (Fig. 2). In less than two decades, Shanghai has — once again metamorphosed into a vibrant capitalist metropolis. The high-rise buildings, six-lane highways, boutiques with world-famous brand names, big neon-light advertisements, McDonalds, KFC, and so forth, that are seen today first appeared in the 1990s. These developments, together with some "hard facts" (such as GDP per capita), support the claims of the state when it flaunts its economic achievements in realizing its grand state project of "modernization" (xiandaihua) (see Croll 1997; Gamble 2001). No one I met in the field could disagree with the assertion that the Shanghainese's quality of life had greatly improved since the economic reforms began in 1978. Most tend to regard "modernization" in a positive light; For instance, in everyday conversation, people's narratives are often imbued with such "official" signifiers as fazhan (development), shichang (market), gaige (reform), and gaibian (change), which echo the state ideology of change, implying that China is making strides toward a "modernized" and "rich and strong" (fuqiang) country. Furthermore, many Shanghainese I met seemed engrossed one way or another in various lucrative (or potentially lucrative) activities that boosted the 


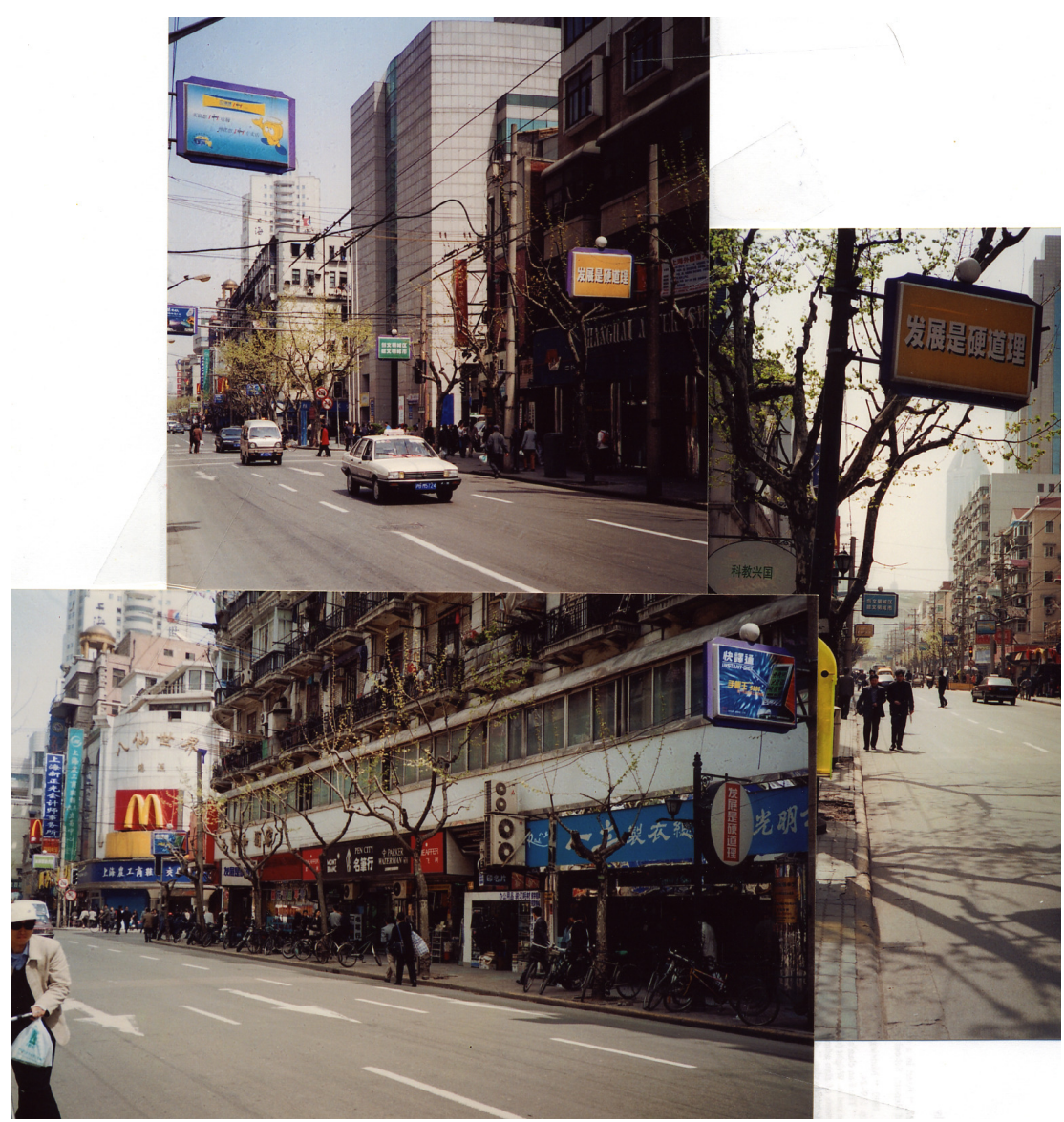

Figure 2. "Development is an unshakable law." (Source: Photos of the author)

market-driven economy (for example, speculating in the stock market, setting up their own businesses), chasing after their own version of modernity — or, in both official and everyday discourse, hoping "to get rich first!"

When I switch from what the state often calls the "roaring tide of the market economy" (shichang jingji de dachao) to the more contemplative mode of research, I am usually intrigued by the (ostensibly) unproblematic acceptance of the ideas of the free-market economy, 
which were vociferously opposed during the Maoist years (1949-67). Just a few decades ago, "We would rather have the grass of socialism than the jewels of capitalism" (cited in Gamble 2001, p.91) was a common revolutionary slogan among the populace. How do postsocialist actors whose identity was once highly glorified, who were once used to acting in response to political calls, and who were once made to live in the frugal manner consistent with socialist ethos understand the "fading out" of socialist politics and face up to the uncertainties that lie ahead? This question was what I had had in mind when I began my study.

Starting in September 2000, I engaged in eleven months of participatory fieldwork in Cucumber Lane. In the pre-Communist period (especially during the 1940s), Cucumber Lane was one of the largest urban slums in Shanghai. I chose that neighborhood for my investigation because it remains the only sizable community in Shanghai (with 1,820 households and roughly 6,300 residents) made up of those who had been the most despised, dispossessed, and "uncivilized" urban subalterns in the semicolonial era. The inhabitants therefore share the same revolutionary past; they live together in a small community (xiaoqu) bounded by a fence, despite Shanghai's rapid urban development of recent years. What is more interesting about Cucumber Lane is that during the Maoist period, it was a very well-known "thought-education base" (sixiang jiaoyu jidi), where both local people and foreigners came to receive "education" conducted by the "old residents" (lao jumin). Having suffered hardship in the semicolonial period, these "old residents" were deeply moved by the drastic improvement in their quality of life once the Chinese Communist Party (CCP) had risen to power in 1949. They were given the revolutionary label "teachers" (daoshi), and were given the task of telling visitors their life stories in such a way that "the goodness of socialism was eulogized" (zanmei shehui zhuyi hao) (Anonymous 1997, p.3). But as fervent collectivism dwindled with the launching of reforms and the opening up of the country in 1978, Cucumber Lane and its residents began to lose its appeal with the public. In fact, many of its second-generation residents, now in their forties and fifties, lament that under the exploitation of the new economic institutions, they have returned to being "proletarians." Thus the unique historical background and politically charged history of the residents of 
Cucumber Lane opens up a rich corpus of ethnographic materials, both historical and contemporary, textual and oral, for me to use in addressing the problem I was investigating. More specifically, the main objective of this book is to examine a specific group of people who had belonged to the lowest rung of society before 1949 and to determine how they and the following generations, who became revolutionary vanguards of the proletarian class during the Maoist era, are making sense of and coping with the radical changes they have experienced since the Communist takeover.

The subsequent chapters will be organized by topics; these tend to follow a diachronic timeline, which works its way roughly from the informants' evaluation of the past to their current expectations of the future. While this organization is mainly for the convenience of readers, it should be noted that the time structures of the informants' biographical narratives never follow a simple past-to-future pattern. Rather, as Peel has astutely suggested, "Making history [on the part of the actor] is really a single process with two strands: the practice of fashioning a future social order entails a constant reevaluation of the past" (1984, p.129).

I have divided the material into seven chapters. Chapter One situates the project in early 2000s Shanghai by discussing the issues related to my orienting to the field as an ethnographer. Also laid down are the key theoretical concepts that guide my analysis of the actors' narratives of experiencing radical social change. Chapter Two introduces in more detail the unique historical background of Cucumber Lane. Central to the discussion is an examination of a specific type of "thought education" (sixiang jiaoyu) called yiku sitian in the making of a socialist "model community" during the Maoist period. Chapter Three looks into the rise of the community-based spirit of collectivism in the service of the revolutionary cause. Here my analysis is extended to the sociopolitical landscape of Cucumber Lane in the pre-Communist period, when the area was still made up of peasant migrants. Chapter Four examines the changing settings of Cucumber Lane at two historical junctures. It argues that the two spatial reorganizations exemplify two major state-led projects of modernity, each of which entails a specific representation of space that ideologically adumbrates a specific course of national development. Chapter Five explores the methods the residents have used 
to negotiate with the changing representations of their political identity in the past half-century. This particular investigation will explicate one set of conditions under which one particular discourse of identity led to hegemony among the residents, while the other set invoked apathy and dissent. Chapter Six focuses on the multiple narrative forms employed by different individuals in response to the rise of "modern living" as a direction toward which both the state and its people believe that China is moving. By drawing on local narratives as well as on observations of the wider public culture of contemporary Shanghai, the chapter highlights various ways in which residents of different age groups are perceiving and moving toward the postsocialist future. In Chapter Seven, the concluding chapter, I attempt to argue that, facing the radical shift in the contexts, from a socialist to a postsocialist condition, actors do not necessarily perceive themselves as living in chaos with intensifying internal struggles. Rather, in encountering the (changing) social structure, they live in an ostensible hegemony in which dominant ideologies are shared without any guarantees of harmony. Such an ostensible hegemony reflects a historic-specific interrelation among the ideological, resource, and value dimensions of the social structure. The Epilogue that follows Chapter Seven outlines the more updated situation of Cucumber Lane I encountered when I revisited Shanghai for the first time in November 2008. These more recent observations constitute a reflection on the analyses I made earlier.

I should note here that this book is made possible by the assistance of many people. My gratitude is first of all due to the people in Cucumber Lane. To express my gratitude to the informants in person, I brought gifts and souvenirs when I revisited the community seven years after completing my fieldwork. Aside from the joy of reunion, several of the old residents had passed away, and some of them were "young" from my point of view. Among the deceased, Mr. V had offered me a great deal of advice and care during my fieldwork; I want to express my special thanks to him.

I would also like to thank my hosts for looking after me and taking care of my needs as I conducted my fieldwork, and especially for letting me have the room, which was originally their son's, at a reduced rate. During my return to Cucumber Lane, I felt more than glad to learn that 
the son had married and the father of a boy who was already eighteen months old.

For academic advice, I am grateful to Dr. Kevin Latham, SOAS, University of London.

I must also express my deepest thank to Prof. Wu Xu-Song, Vicechairman of the Institute of Sociology, Shanghai Academy of Social Sciences; Prof. Liu Qi-Kui, Vice-director of the Office of the Shanghai History Gazette; and Prof. Peng Xi-Zhe, Chairman of the Institute of Demography, Shanghai Fudan University, not only for their intellectual input, but also for the practical assistance in the field that they sincerely offered me during my fieldwork.

My special thanks go to Murakami Daisuke, Miura Keiko, and Claudio Chow for their friendship and emotional support during my years of study in London.

I would also like to take this opportunity to thank the senior colleagues of the Department of Applied Social Studies, City University of Hong Kong, in particular, Prof. Alex Kwan Yui-Huen, Dr. Raymond Chan Kwok-Hong, and Dr. Leung Kwan-Kwok, whose support have been crucial to my personal and intellectual development.

I owe much to my wife who has been extraordinarily patient with my long course of study, albeit not without complaints. I hope that this book provides a small return on the many sacrifices she made while I was spending years at a time conducting fieldwork in Shanghai, studying in London, and struggling for jobs and a livelihood when I returned to Hong Kong.

It should be noted that various chapters of this book draw in varying degrees on my previously published articles: "Experiencing the Destatization of the Family Ritual in Postsocialist China: Morality, Resource and State Power," The Journal of Comparative Asian Development, 7, 2, (2008), pp.231-259; "The (Un-)Making the Shanghai Socialist 'Model Community': From the Monolithic to Heterogeneous Appropriation(s) of the Past," Journal of Asian and African Studies, 39, 5, (2004), pp.379-405; "From Resistance to Collective Action in a Shanghai Socialist 'Model Community': From the Late 1940s to Early 70s," Journal of Social History, 40, 1, (2006), pp.85-117; "Building up Modernity?: The Changing Spatial Representations of State Power in a 
Chinese Socialist 'Model Community'," Modern Asian Studies, 42, 6, (2008), pp.1137-1171; "Negotiating Subalternity in a Former Socialist 'Model Community' in Shanghai: From 'Model Proletarians' to 'Society People'," The Asia Pacific Journal of Anthropology, 6, 2, (2005), pp.159-180; "Public Amnesia and Multiple Modernities in Shanghai: Narrating the Postsocialist Future in a Former Socialist 'Model Community'," Journal of Contemporary Ethnography, 37, (2008), pp.383-416 (with $\mathrm{Ng}$, Yat-Nam). I am grateful to the publishers for permission to use copyrighted materials.

W.C. Ho 


\section{CONTENTS}

Preface vii

1. Encountering a Forgotten People, Experiencing Social Change 1

2. The (Un-) Making of a Socialist "Model Community": Heterogeneous Appropriations of the Past

3. Binding Up the "Loose Sand": The Rise and Fall of Collectivism 63

4. Building Up Modernity: The Spatial Representations of State Power 109

5. Negotiating Subalternity: "Model Proletarians" or "Society People"? 145

6. Facing Up to the Postsocialist Future: Public Amnesia and Multiple Modernities

7. Conclusion: Experiencing an Ideology that Truncates Time and Space 205

8. Epilogue: Revisiting Cucumber Lane in 2008

Appendix A: Materials and Methodology 225

Appendix B: The "Origins" of "Cucumber Lane" 235

Appendix C: Glossary of Chinese Terms 237

$\begin{array}{ll}\text { Bibliography } & 245\end{array}$

$\begin{array}{ll}\text { Index } & 261\end{array}$ 